Prepared in cooperation with the U.S. Army Corps of Engineers, St. Louis Metropolitan Sewer District, Missouri Department of Transportation, Missouri American Water, and Federal Emergency Management Agency Region 7

\title{
Flood-Inundation Maps for the Meramec River at Valley Park and at Fenton, Missouri, 2017
}

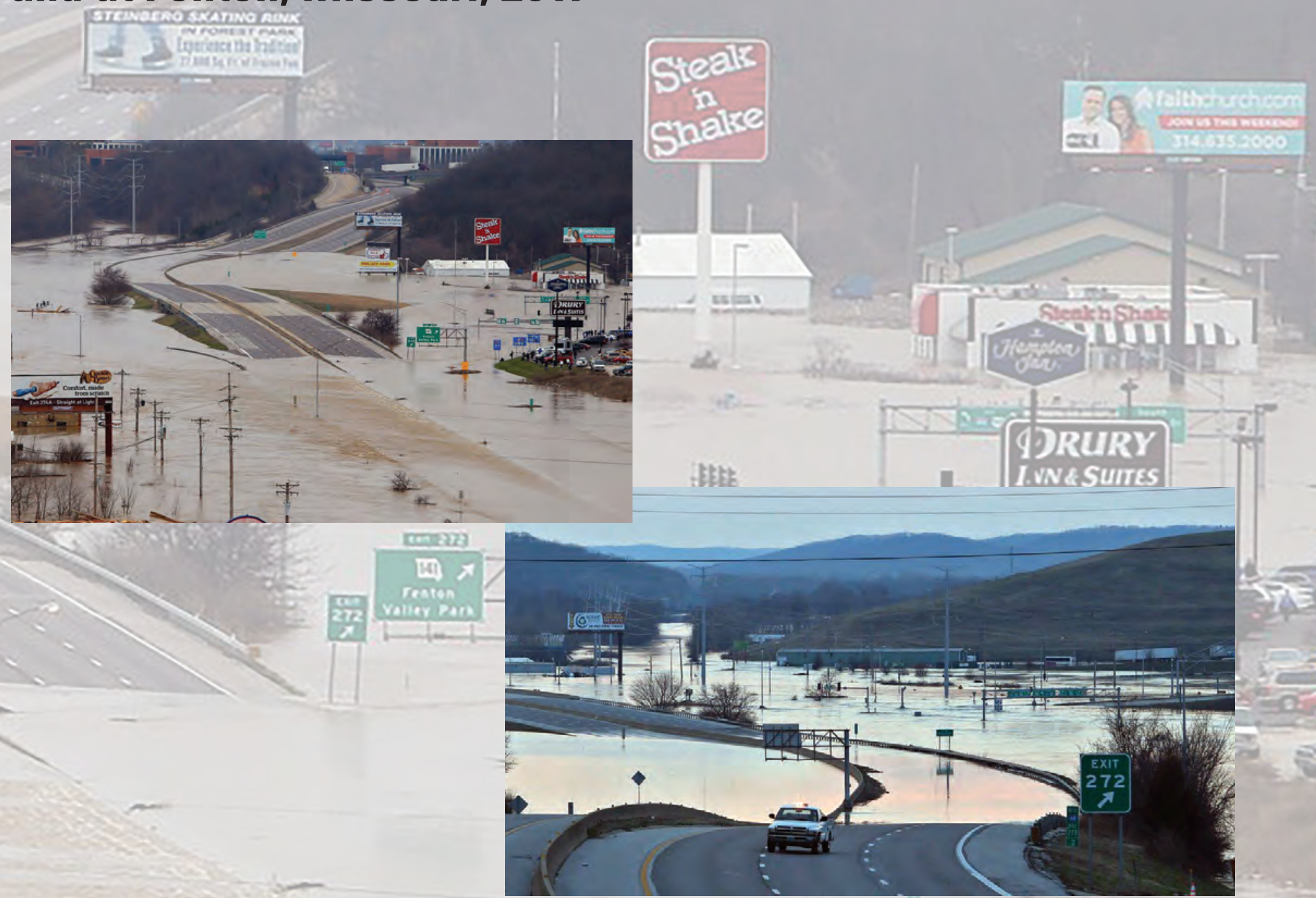

Scientific Investigations Report 2017-5116

U.S. Department of the Interior

U.S. Geological Survey 
Cover. Flooding from the Meramec River in Valley Park, Missouri. Upper left photograph taken December 30, 2015, by David Carson, St. Louis Post-Dispatch, used with permission. Lower right photograph taken December 31, 2015, by J.B. Forbes, St. Louis Post-Dispatch, used with permission.

Back cover. Flooding from the Meramec River near Eureka, Missouri, December 30, 2015. Photographs by David Carson, St. Louis Post-Dispatch, used with permission. 


\section{Flood-Inundation Maps for the Meramec River at Valley Park and at Fenton, Missouri, 2017}

By Benjamin J. Dietsch and Jacob N. Sappington

Prepared in cooperation with the U.S. Army Corps of Engineers, St. Louis Metropolitan Sewer District, Missouri Department of Transportation, Missouri American Water, and Federal Emergency Management Agency Region 7

Scientific Investigations Report 2017-5116 


\title{
U.S. Department of the Interior \\ RYAN K. ZINKE, Secretary
}

\section{U.S. Geological Survey William H. Werkheiser, Acting Director}

\author{
U.S. Geological Survey, Reston, Virginia: 2017
}

For more information on the USGS - the Federal source for science about the Earth, its natural and living resources, natural hazards, and the environment-visit https://www.usgs.gov or call 1-888-ASK-USGS.

For an overview of USGS information products, including maps, imagery, and publications, visit https://store.usgs.gov.

Any use of trade, firm, or product names is for descriptive purposes only and does not imply endorsement by the U.S. Government.

Although this information product, for the most part, is in the public domain, it also may contain copyrighted materials as noted in the text. Permission to reproduce copyrighted items must be secured from the copyright owner.

Suggested citation:

Dietsch, B.J., and Sappington, J.N., 2017, Flood-inundation maps for the Meramec River at Valley Park and at Fenton, Missouri, 2017: U.S. Geological Survey Scientific Investigations Report 2017-5116, 12 p., https://doi.org/10.3133/ sir20175116.

ISSN 2328-0328 (online) 


\section{Contents}

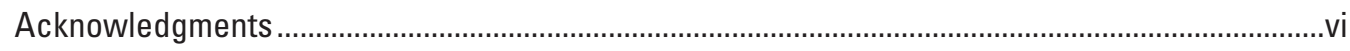

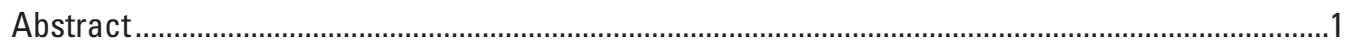

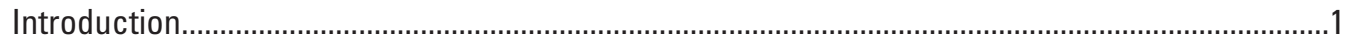

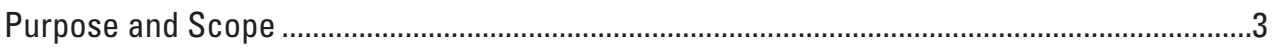

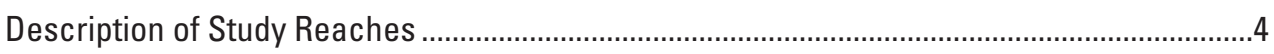

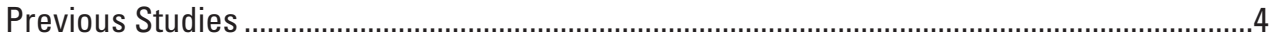

Creation of Flood-Inundation Map Library .......................................................................................

Computation of Water-Surface Profiles.................................................................................... 4

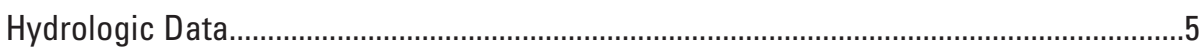

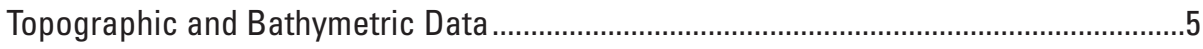

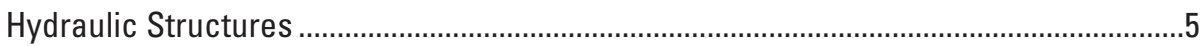

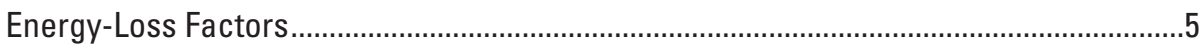

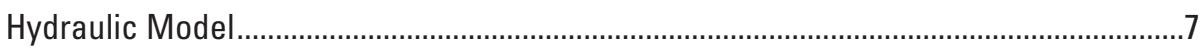

Development of Water-Surface Profiles...............................................................................

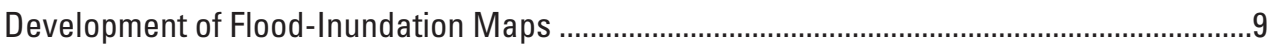

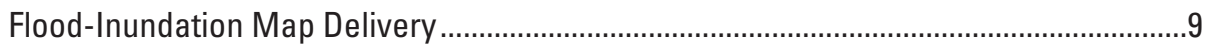

Disclaimer for Flood-Inundation Maps ...............................................................................9

Uncertainties and Limitations Regarding Use of Flood-Inundation Maps ......................11

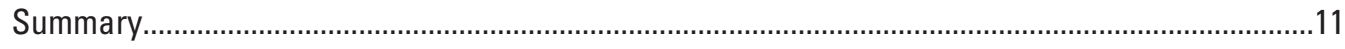

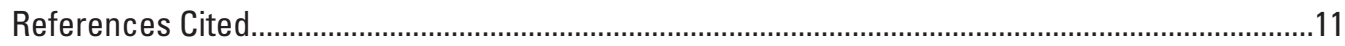




\section{Figures}

1. Map showing location of study reaches for the Meramec River from Valley Park to Fenton, Missouri, and locations of the cooperative U.S. Geological Survey streamgages along the lower Meramec River.....

2. Graph showing comparison of hydraulic-model output and stage-discharge rating at Meramec River near Eureka, Missouri

3. Graph showing comparison of hydraulic-model output and high-water mark elevations for a major flood event on December 30, 2015, Meramec River, Missouri......8

4. Flood-inundation map for the Meramec River at Valley Park, Missouri, reach corresponding to a stage of 44 feet at the cooperative U.S. Geological Survey streamgage and Meramec River at Fenton, Missouri, reach corresponding to a stage of 42 feet at the U.S. Geological Survey streamgage

\section{Tables}

1. Information for U.S. Geological Survey streamgages along or near the study reaches, Meramec River at Valley Park and at Fenton, Missouri.

2. Peak discharges for selected annual exceedance probabilities for the Meramec River near Eureka, Missouri

3. Estimated discharges for corresponding stages and water-surface elevations at selected locations in the hydraulic model of the Meramec River from Eureka, Missouri, to Arnold, Missouri 


\section{Conversion Factors}

U.S. customary units to International System of Units

\begin{tabular}{|c|c|c|}
\hline Multiply & By & To obtain \\
\hline \multicolumn{3}{|c|}{ Length } \\
\hline foot $(\mathrm{ft})$ & 0.3048 & meter $(\mathrm{m})$ \\
\hline foot $(\mathrm{ft})$ & 30.48 & centimeter $(\mathrm{cm})$ \\
\hline mile (mi) & 1.609 & kilometer $(\mathrm{km})$ \\
\hline \multicolumn{3}{|c|}{ Area } \\
\hline square mile $\left(\mathrm{mi}^{2}\right)$ & 2.590 & square kilometer $\left(\mathrm{km}^{2}\right)$ \\
\hline acre-foot (acre-ft) & 0.001233 & cubic hectometer $\left(\mathrm{hm}^{3}\right)$ \\
\hline \multicolumn{3}{|c|}{ Flow rate } \\
\hline cubic foot per second $\left(\mathrm{ft}^{3} / \mathrm{s}\right)$ & 0.02832 & cubic meter per second $\left(\mathrm{m}^{3} / \mathrm{s}\right)$ \\
\hline
\end{tabular}

\section{Datum}

Vertical coordinate information is referenced to (1) stage, the height above an arbitrary datum established at a streamgage, and (2) elevation, the height above the North American Vertical Datum of 1988 (NAVD 88).

Horizontal coordinate information is referenced to the North American Datum of 1983 (NAD 83). 


\section{Acknowledgments}

The authors wish to thank the U.S. Army Corps of Engineers St. Louis District and the Metropolitan St. Louis Sewer District for funding the operation and maintenance of the streamgages used for this study. Special thanks are given to the National Weather Service for their continued support of the U.S. Geological Survey flood-inundation mapping program. 


\title{
Flood-Inundation Maps for the Meramec River at Valley Park and at Fenton, Missouri, 2017
}

\author{
By Benjamin J. Dietsch and Jacob N. Sappington
}

\section{Abstract}

Two sets of digital flood-inundation map libraries that spanned a combined 16.7-mile reach of the Meramec River that extends upstream from Valley Park, Missouri, to downstream from Fenton, Mo., were created by the U.S. Geological Survey (USGS) in cooperation with the U.S. Army Corps of Engineers, St. Louis Metropolitan Sewer District, Missouri Department of Transportation, Missouri American Water, and Federal Emergency Management Agency Region 7. The floodinundation maps, which can be accessed through the USGS Flood Inundation Mapping Science website at https://water. usgs.gov/osw/flood_inundation/, depict estimates of the areal extent and depth of flooding corresponding to selected water levels (stages) at the cooperative USGS streamgages on the Meramec River at Valley Park, Mo., (USGS station number 07019130) and the Meramec River at Fenton, Mo. (USGS station number 07019210). Near-real-time stage data at these streamgages may be obtained from the USGS National Water Information System at https://waterdata.usgs.gov/nwis or the National Weather Service (NWS) Advanced Hydrologic Prediction Service at http:/water.weather.gov/ahps/, which also forecasts flood hydrographs at these sites (listed as NWS sites vllm7 and fnnm7, respectively).

Flood profiles were computed for the stream reaches by means of a calibrated one-dimensional step-backwater hydraulic model. The model was calibrated using a stage-discharge relation at the Meramec River near Eureka streamgage (USGS station number 07019000) and documented high-water marks from the flood of December 2015 through January 2016.

The calibrated hydraulic model was used to compute two sets of water-surface profiles: one set for the streamgage at Valley Park, Mo. (USGS station number 07019130), and one set for the USGS streamgage on the Meramec River at Fenton, Mo. (USGS station number 07019210). The water-surface profiles were produced for stages at 1-foot (ft) intervals referenced to the datum from each streamgage and ranging from the NWS action stage, or near bankfull discharge, to the stage corresponding to the estimated 0.2 -percent annual exceedance probability (500-year recurrence interval) flood, as determined at the Eureka streamgage (USGS station number 07019000). The simulated water-surface profiles were then combined with a geographic information system digital elevation model (derived from light detection and ranging data having a $0.28-\mathrm{ft}$ vertical accuracy and 3.28-ft horizontal resolution) to delineate the area flooded at each flood stage (water level).

The availability of these maps, along with internet information regarding current stage from the USGS streamgages and forecasted high-flow stages from the NWS, will provide emergency management personnel and residents with information that is critical for flood response activities such as evacuations and road closures and for postflood recovery efforts.

\section{Introduction}

The cities of Valley Park and Fenton, Missouri, along the lower Meramec River (fig. 1) in southern St. Louis County have estimated populations of 6,942 and 4,022, respectively (U.S. Census Bureau, 2010). The Meramec River is one of the longest free-flowing rivers in Missouri, and its flood plain has numerous developed areas along the downstream part of the drainage basin in St. Louis County (Missouri Department of Natural Resources, 2015). Valley Park and Fenton have experienced severe flooding numerous times, most recently in 1982, 2008, 2015, and 2017. The highest observed flood at the cooperative U.S. Geological Survey (USGS) streamgage on the Meramec River at Valley Park, Mo., (USGS station number 07019130) was recorded in December 2015 at a stage of 44.11 feet (ft) (National Weather Service, 2017a). The flooding during December 2015 through January 2016 affected many commercial and residential areas, water supply and treatment facilities, and transportation infrastructure along the lower Meramec River.

Before this study, emergency responders in St. Louis and Jefferson Counties (fig. 1) relied on several information sources (all are available on the internet) to make decisions on how to best alert the public and mitigate flood damages. One source is the Federal Emergency Management Agency flood insurance studies (more commonly known as FIS) for St. Louis County (Federal Emergency Management Agency, 2015). A second source of information is the USGS streamgage data (available at https://mo.water.usgs.gov/) 


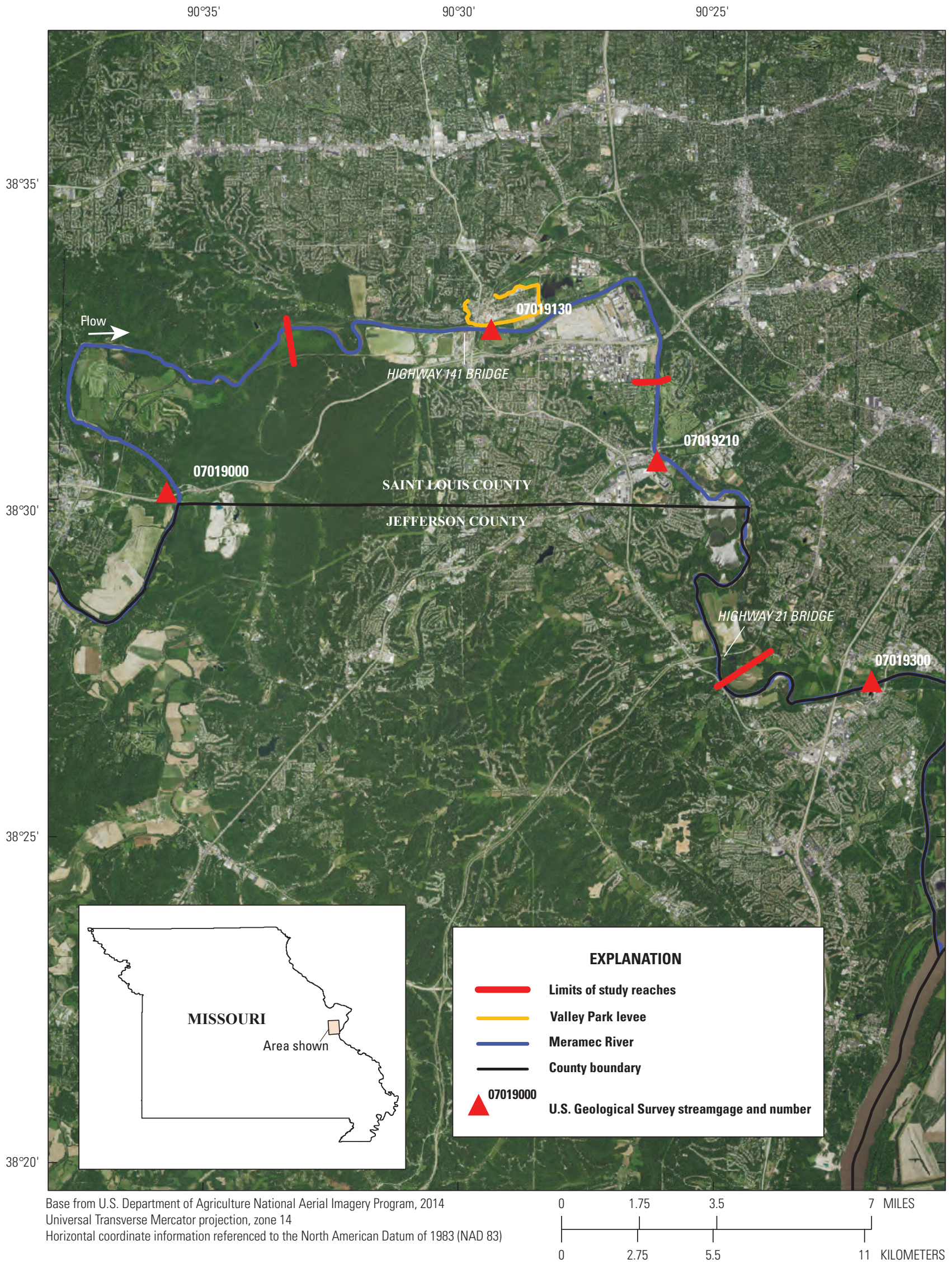

Figure 1. Location of study reaches for the Meramec River from Valley Park to Fenton, Missouri, and locations of the cooperative U.S. Geological Survey streamgages along the lower Meramec River. 
from which current (2017) or historical water levels (stages) and discharges, including annual peak flows, can be obtained. A third source of flood-related information is the National Weather Service (NWS) Advanced Hydrologic Prediction Service (AHPS), which displays measured stage data and issues forecasts of stage for the cooperative USGS streamgage Meramec River at Valley Park, Mo., (USGS station number 07019130) and the USGS streamgage Meramec River at Fenton, Mo., (USGS station number 07019210) (National Weather Service, 2017a).

Although the current stage at a USGS streamgage is particularly useful for residents near a streamgage, it is of little use to residents farther upstream or downstream because the water-surface elevation is not constant along the entire stream reach. Knowledge of a water level at a streamgage is difficult to translate into depth and areal extent of flooding at points distant from the streamgage. One way to address these informational gaps is to produce a library of flood-inundation maps that are referenced to the stages recorded at the USGS streamgage. By referring to the appropriate map, emergency responders can discern the severity of flooding (depth of water and areal extent), identify roads that are or will soon be flooded, and make plans for notification or evacuation of residents in harm's way for some distance upstream and downstream from the streamgage. In addition, the capability to visualize the potential extent of flooding may motivate residents to take precautions and heed warnings that they previously might have disregarded. In 2016-17, the USGS, in cooperation with the U.S. Army Corps of Engineers, St. Louis Metropolitan Sewer District, Missouri Department of Transportation, Missouri American Water, and Federal Emergency Management Agency Region 7 completed a project to produce a library of flood-inundation maps for two reaches on the lower Meramec River extending from upstream from Valley Park, Mo., to downstream from Fenton, Mo.

\section{Purpose and Scope}

This report describes the development of a series of estimated flood-inundation maps for a 16.7-mile (mi) reach of the Meramec River from upstream from Valley Park to downstream from Fenton, Mo., and identifies where on the internet the maps can be viewed and ancillary data (geographic information system flood polygons and depth grids) can be downloaded. The flood inundation maps cover a reach of the lower Meramec River from 4.1 mi upstream from the Missouri Highway 141 bridge at Valley Park to 1.2 miles downstream from the Missouri Highway 21 bridge at Fenton (fig. 1). The maps were produced for water levels referenced to the stages recorded at the cooperative USGS streamgage 07019130, Meramec River at Valley Park, Mo., and USGS streamgage 07019210, Meramec River at Fenton, Missouri (fig. 1 and table 1). The upstream $9.1 \mathrm{mi}$ is associated with the streamgage at Valley Park and is herein referred to as the Valley Park reach. The downstream $7.6 \mathrm{mi}$ is associated with the streamgage at Fenton and is herein referred to as the Fenton reach. The maps cover a range in stage from 11 to $53 \mathrm{ft}$, referenced to the streamgage datum, at streamgage 07019130 and from 22 to $46 \mathrm{ft}$, referenced to the streamgage datum, at streamgage 07019210 . The $11-\mathrm{ft}$ stage at streamgage 07019130 and the $22-\mathrm{ft}$ stage at streamgage 07019210 are stages defined by the NWS as the "action stage" or that stage that, when reached by a rising stream, requires the NWS or a partner to take some type of mitigation action in preparation for possible substantial hydrologic activity (National Weather Service, 2017b). The maximum stage at each streamgage for the estimated floodinundation maps exceeds the "major flood stage" as defined by the National Weather Service $(25 \mathrm{ft}$ at 07019130 and $32 \mathrm{ft}$ at 07019210); exceeds the maximum recorded stage at both streamgages; and is the stage that corresponds to a flow rate of

Table 1. Information for U.S. Geological Survey streamgages along or near the study reaches, Meramec River at Valley Park and at Fenton, Missouri.

[Station location is shown in figure 1. $\mathrm{mi}^{2}$, square miles; ft, feet; NAVD 88, North American Vertical Datum of 1988; fts, cubic feet per second; Mo., Missouri;

○, degrees; ', minutes; ", seconds]

\begin{tabular}{|c|c|c|c|c|c|c|c|}
\hline $\begin{array}{l}\text { Station name } \\
\text { (fig. 1) }\end{array}$ & $\begin{array}{l}\text { Station } \\
\text { number }\end{array}$ & $\begin{array}{c}\text { Drainage } \\
\text { area } \\
\left(\mathrm{mi}^{2}\right)\end{array}$ & Latitude & Longitude & Period of record & $\begin{array}{c}\text { Maximum } \\
\text { recorded stage } \\
\text { (ft, NAVD 88) and date }\end{array}$ & $\begin{array}{c}\text { Maximum discharge } \\
\left(\mathrm{ft}^{3} / \mathrm{s}\right) \\
\text { and date }\end{array}$ \\
\hline Meramec River near Eureka, Mo. & 07019000 & 3,788 & $38^{\circ} 30^{\prime} 17^{\prime \prime}$ & $90^{\circ} 35^{\prime} 27^{\prime \prime}$ & $\begin{array}{l}1904,1905,1915,1916 \\
1922-2016\end{array}$ & $\begin{array}{c}46.06 \\
(449.90) \\
\text { December 30, } 2015\end{array}$ & $\begin{array}{c}162,000 \\
\text { December 30, } 2015\end{array}$ \\
\hline Meramec River at Valley Park, Mo. & 07019130 & 3,850 & $38^{\circ} 32^{\prime} 48^{\prime \prime}$ & $90^{\circ} 29^{\prime} 06^{\prime \prime}$ & 1915-2017 (stage only) & $\begin{array}{c}44.11 \\
(435.33) \\
\text { December } 31,2015\end{array}$ & Not applicable \\
\hline Meramec River at Fenton, Mo. & 07019210 & 3,872 & $38^{\circ} 30^{\prime} 44^{\prime \prime}$ & $90^{\circ} 25^{\prime} 53^{\prime \prime}$ & 2016-Present (stage only) & $\begin{array}{c}19.46 \\
(402.22) \\
\text { May } 14,2016\end{array}$ & Not applicable \\
\hline Meramec River at Arnold, Mo. & 07019300 & 3,950 & $38^{\circ} 27^{\prime} 24^{\prime \prime}$ & $90^{\circ} 21^{\prime} 38^{\prime \prime}$ & $\begin{array}{l}\text { 1973, 1979-2017 (stage } \\
\text { only) }\end{array}$ & $\begin{array}{c}47.26 \\
(420.09) \\
\text { December 31, } 2015\end{array}$ & Not applicable \\
\hline
\end{tabular}


about 227,000 cubic feet per second $\left(\mathrm{ft}^{3} / \mathrm{s}\right)$ at the USGS cooperative streamgage Meramec River near Eureka, Mo. (USGS station number 07019000), which is the estimated 0.2-percent annual exceedance probability (500-year recurrence interval) flood (Holmes and others, 2016).

\section{Description of Study Reaches}

The Meramec River Basin in eastern Missouri is primarily in the Ozark Highlands ecoregion (Omernik, 1987). The basin terrain is characterized by gently rolling to moderately hilly topography. The drainage areas of streamgages within the study reach range from about 3,850 square miles $\left(\mathrm{mi}^{2}\right)$ at the Meramec River at Valley Park streamgage near the upstream study limit to about 3,950 $\mathrm{mi}^{2}$ at the downstream study limit. No large tributaries join the Meramec River within the study reach, although several streams with drainage areas less than $25 \mathrm{mi}^{2}$ enter the Meramec River along the study reach. The total study reach is about $16.7 \mathrm{mi}$ long $(9.1 \mathrm{mi}$ for the Valley Park reach and $7.6 \mathrm{mi}$ for the Fenton reach) and has an average top-of-bank channel width of about $320 \mathrm{ft}$ and an average channel slope of 1.6 feet per mile. Most of the land contiguous to the study reach is urban or developed. The main channel within the study reach has six road crossings or other structures (railroad, roadway, and pedestrian bridges) as of February 2017. Levee-protected areas are behind the Valley Park levee system (fig. 1). The levee-protected areas are included in the U.S. Army Corps of Engineers National Levee Database (U.S. Army Corps of Engineers, 2017).

\section{Previous Studies}

The current FIS for St. Louis County, Mo., and incorporated areas (Federal Emergency Management Agency, 2015) was last revised by Missouri State Emergency Management Agency (SEMA) and AMEC Earth \& Environmental, Inc., (AMEC) in 2015.

A USGS report examining characteristics of flooding in the Meramec River Basin in December 2015-January 2016 presents estimates of the peak discharges with 2-, 1-, and 0.2-percent annual exceedance probabilities for the Meramec River near Eureka, Mo. (table 2) (Holmes and others, 2016). The estimated annual exceedance probability corresponding to the December 2015 flood at the Meramec River near Eureka, Mo., streamgage was 1.1 percent, with a 66.7-percent confidence interval for the true annual exceedance probability of the flood extending from 0.7 to 3.2 percent. The observed peak discharge of $162,000 \mathrm{ft}^{3} / \mathrm{s}$ for the December 2015 flood falls within the estimated 2-percent annual exceedance flow of $140,000 \mathrm{ft}^{3} / \mathrm{s}$ and the estimated 1-percent annual exceedance flow of $165,000 \mathrm{ft}^{3} / \mathrm{s}$ based on 99 years of peak record used in the analysis. The estimated flood discharges and their corresponding stages at the Meramec River near Eureka streamgage were used in the determination of the range of simulated flows in the development of the floodinundation maps for the Meramec River at Valley Park and the
Meramec River at Fenton streamgages, because no discharge data were available for these streamgages.

Table 2. Peak discharges for selected annual exceedance probabilities for the Meramec River near Eureka, Missouri.

[Data from Holmes and others, 2016. $\mathrm{mi}^{2}$, square miles; $\mathrm{ft}^{3} / \mathrm{s}$, cubic feet per second; USGS, U.S. Geological Survey]

\begin{tabular}{ccccc}
\hline $\begin{array}{c}\text { Location on } \\
\text { Meramec River }\end{array}$ & $\begin{array}{c}\text { Drainage } \\
\text { area } \\
\left(\mathbf{m i}^{2}\right)\end{array}$ & $\begin{array}{c}\text { Estimated discharges }\left(\mathbf{f t}^{3} / \mathbf{s}\right) \text { for } \\
\text { indicated annual exceedance } \\
\text { probabilities (in percent) }\end{array}$ \\
\hline At USGS streamgage & 3,788 & 140,000 & 165,000 & 227,000 \\
number 07019000 & & $(2)$ & $(1)$ & $(0.2)$ \\
\hline
\end{tabular}

\section{Creation of Flood-Inundation Map Library}

The USGS has standardized the procedures for creating flood-inundation maps for flood-prone communities (U.S. Geological Survey, 2017a) so that the process followed and products produced are similar regardless of the USGS office that is responsible for the work. Tasks specific to developing the flood maps for the Meramec River at Valley Park and at Fenton, Mo., were (1) acquiring the hydraulic model that was developed by the U.S. Army Corps of Engineers St. Louis District (U.S. Army Corps of Engineers, written commun., 2016); (2) refining energy-loss factors (roughness coefficients) in the stream channel and flood plain by calibration; (3) computing water-surface profiles using the U.S. Army Corps of Engineers Hydrologic Engineering Centers River Analysis System (HEC-RAS) computer program (Brunner, 2016); (4) producing estimated flood-inundation maps at several stream stages for two reaches using the U.S. Army Corps of Engineers Hydrologic Engineering Centers Geospatial River Analysis System (HEC-GeoRAS) computer program (Ackerman, 2009) and a geographic information system (GIS); and (5) preparing the maps, as shapefile polygons that depict the areal extent of flood inundation and as depth grids that provide the depth of floodwaters, for display on a USGS floodinundation mapping application.

\section{Computation of Water-Surface Profiles}

The water-surface profiles used to produce the 72 floodinundation maps in this study were computed using HECRAS, version 5.0.3 (Brunner, 2016). The HEC-RAS model is a one-dimensional step-backwater hydraulic model that simulates water-surface profiles with unsteady-state flow computation options. The simulation reach, which was for a longer section of the river than the study reaches, started near the location of the cooperative USGS streamgage Meramec River near Eureka, Mo., and extended $28.4 \mathrm{mi}$ downstream to the location of the cooperative USGS streamgage Meramec River at Arnold, Mo. (USGS station number 07019300) (fig. 1). 


\section{Hydrologic Data}

The study reaches included one stage-only streamgage, streamgage 07019130, during the flood of December 2015, but soon after, in January 2016, streamgage 07019210 was installed on the Meramec River in Fenton, Mo. (fig. 1; table 1). Stage is measured every 15 minutes at streamgage 07019130 and every 5 minutes at streamgage 07019210 , transmitted hourly by a satellite radio in each streamgage, and made available on the internet through the USGS National Water Information System (U.S. Geological Survey, 2017b). Stage data from the streamgages are referenced to a local streamgage datum but can be converted to water-surface elevations referenced to the North American Vertical Datum of 1988 (NAVD 88) by adding $391.22 \mathrm{ft}$ for streamgage 07019130 and $382.76 \mathrm{ft}$ for streamgage 07019210 .

Stages ranging from $410 \mathrm{ft}$ to $462 \mathrm{ft}$, NAVD 88 , at the Eureka streamgage were used as input into the hydraulic model to produce water-surface profiles corresponding to selected stages at streamgages 07019130 and 07019210 (table 3). No large tributaries join the Meramec River within the $28.4 \mathrm{mi}$ simulation reach; therefore, additional discharges were not added for tributary inflows. Normal depths were used as a downstream model constraint for model calibration, and stage data collected at the Meramec River at Valley Park streamgage were used for model verification for the simulation of the December 2015-January 2016 flood on the Meramec River.

\section{Topographic and Bathymetric Data}

All topographic data used in this study are referenced vertically to NAVD 88 and horizontally to the North American Datum of 1983. Cross section elevation data were obtained from a digital elevation model (DEM) that was derived from light detection and ranging (lidar) data that were collected by Surdex Corporation on January 29-30 and February 1, 2012 (Surdex Corporation, 2012a). Postprocessing of these data was completed by Surdex Corporation in April 2012. The original lidar data have a horizontal resolution of $2.8 \mathrm{ft}$ ( 0.86 meters) and vertical accuracy of $0.55 \mathrm{ft}$ (16.7 centimeters) at a 95-percent confidence level for the "open terrain" land-cover category (root mean squared error of $0.28 \mathrm{ft}$ [8.5 centimeters]) (Surdex Corporation, 2012b). By these criteria, the lidar data support production of 2-ft contours (Dewberry, 2012); the final DEM, which was resampled to a 3.28 -ft grid-cell size, has a vertical accuracy of plus or minus $1 \mathrm{ft}$. Elevation data were extracted from the DEM for 131 cross sections in the modeled reach using HEC-GeoRAS, a set of procedures, tools, and utilities for processing geospatial data in ArcGIS, and, subsequently, were input to the HEC-RAS model. Because lidar data cannot provide ground elevations below the water surface of a stream, channel cross sections were surveyed by Hanson Professional Engineering Services, on contract for the U.S. Army Corps of Engineers St. Louis District, during 2015.
Cross-sectional depths were measured using hydroacoustic instrumentation at 86 locations within the simulation reach.

Where possible, DEM-generated cross sections were made to coincide with the locations of the within-channel field-surveyed cross sections; within-channel data were directly merged with the DEM data for these cross sections. For all other cross sections, the within-channel data were estimated by interpolation from the closest field-surveyed cross section.

\section{Hydraulic Structures}

Six structures, consisting of road and railroad crossings, have the potential to affect water-surface elevations during floods along the study reaches (12 total in the simulation reach). Bridge-geometry data were obtained from field surveys completed by Hanson Professional Engineering Services, on contract for the U.S. Army Corps of Engineers St. Louis District (U.S. Army Corps of Engineers, written commun., 2016) and were obtained from the Missouri Department of Transportation (Missouri Department of Transportation, written commun., 2016).

Nine lateral structures were modeled to facilitate the simulation of flow from the main river channel to storage areas. The lateral structures represented the natural ground that separates the main river channel from a storage area such as a lake, tributary flood plain, or low-lying area. Because the lateral flow structures represent an overland flow interface between the river channel and flood plain, weir coefficients of 0.2 were used instead of values typically used for inline weirs (1.0-2.2) (King and Brater, 1963).

The community of Valley Park contains a levee that is included in the National Levee Database (U.S. Army Corps of Engineers, 2017). The Valley Park levee system levees about 380 acres on the north bank of the Meramec River. The levee was simulated in the HEC-RAS model as a lateral structure with the area within the levee being represented as a storage area. For inundation mapping purposes, the landward side of the levee is shown as an "area of uncertainty," because there is uncertainty as to how this area would be inundated in the event of the levee overtopping or failing. The calibration run of the hydraulic model for the December 2015 flood event indicated that the Valley Park levee was not overtopped during that event, in concordance with observation. The run of the hydraulic model used to create flood-inundation maps indicated that the water surface would exceed the levee for the water surface profiles corresponding to stages greater than $45 \mathrm{ft}$ (436.22 ft, NAVD 88) for Meramec River at Valley Park, Mo. (USGS station number 07019130).

\section{Energy-Loss Factors}

Hydraulic analyses require the estimation of energy losses that result from frictional resistance exerted on flow in a channel. These frictional resistance energy losses are quantified by the Manning's roughness coefficient ( $n$ value). Initial 
Table 3. Estimated discharges for corresponding stages and water-surface elevations at selected locations in the hydraulic model of the Meramec River from Eureka, Missouri, to Arnold, Missouri.

[ft, feet; NAVD 88, North American Vertical Datum of 1988; ft³/s, cubic feet per second; --, no data]

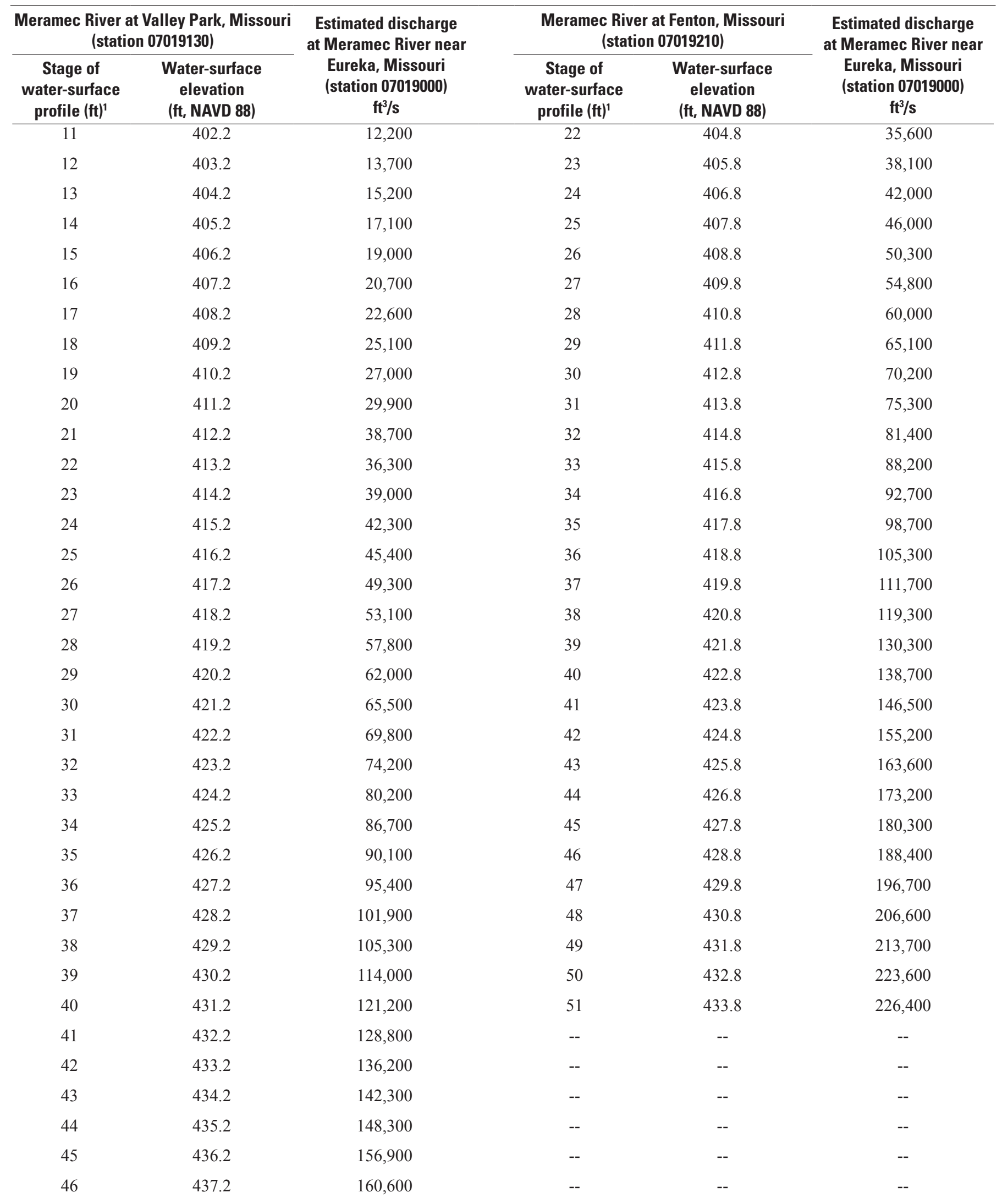


Table 3. Estimated discharges for corresponding stages and water-surface elevations at selected locations in the hydraulic model of the Meramec River from Eureka, Missouri, to Arnold, Missouri.-Continued

[ft, feet; NAVD 88, North American Vertical Datum of 1988; ft³/s, cubic feet per second; --, no data]

\begin{tabular}{|c|c|c|c|c|c|}
\hline \multicolumn{2}{|c|}{$\begin{array}{c}\text { Meramec River at Valley Park, Missouri } \\
\text { (station 07019130) }\end{array}$} & \multirow{2}{*}{$\begin{array}{l}\text { Estimated discharge } \\
\text { at Meramec River near } \\
\text { Eureka, Missouri } \\
\text { (station 0701900) } \\
\mathrm{ft}^{3} / \mathrm{s}\end{array}$} & \multicolumn{2}{|c|}{$\begin{array}{c}\text { Meramec River at Fenton, Missouri } \\
\text { (station 07019210) }\end{array}$} & \multirow{2}{*}{$\begin{array}{l}\text { Estimated discharge } \\
\text { at Meramec River nea } \\
\text { Eureka, Missouri } \\
\text { (station 07019000) } \\
\mathrm{ft}^{3} / \mathrm{s}\end{array}$} \\
\hline $\begin{array}{c}\text { Stage of } \\
\text { water-surface } \\
\text { profile }(\mathrm{ftt})^{1}\end{array}$ & $\begin{array}{l}\text { Water-surface } \\
\text { elevation } \\
\text { (ft, NAVD 88) }\end{array}$ & & $\begin{array}{c}\text { Stage of } \\
\text { water-surface } \\
\text { profile }(\mathrm{ft})^{1}\end{array}$ & $\begin{array}{l}\text { Water-surface } \\
\text { elevation } \\
\text { (ft, NAVD 88) }\end{array}$ & \\
\hline 47 & 438.2 & 166,700 & -- & -- & -- \\
\hline 48 & 439.2 & 173,300 & -- & -- & -- \\
\hline 49 & 440.2 & 181,100 & -- & -- & -- \\
\hline 50 & 441.2 & 190,100 & -- & -- & -- \\
\hline 51 & 442.2 & 198,500 & -- & -- & -- \\
\hline 52 & 443.2 & 206,500 & -- & -- & -- \\
\hline 53 & 444.2 & 216,500 & -- & -- & -- \\
\hline 54 & 445.2 & 226,900 & -- & -- & -- \\
\hline
\end{tabular}

${ }^{1}$ Water-surface profiles are 1-foot increments of stage, referenced to the gage datum of the cooperative U.S. Geological Survey streamgages, Meramec River at Valley Park, Missouri (station number 07019130) and Meramec River at Fenton, Missouri (station number 07019210).

(pre-calibration) Manning's roughness coefficients ( $n$ values) for energy-loss (friction-loss) calculations were estimated by comparing high-resolution aerial photographs and cross-sectional views of the Meramec River channel and photographs of channels for which $n$ values have been computed and published in references such as Barnes (1967) and Coon (1998). The main channel of the Meramec River within the simulation reach consisted of a gravel bed bottom with different amounts of vegetation encroachment from the channel banks. A range in initial $n$ values from 0.040 to 0.050 was selected for the main channel. The flood plains have a variety of land use characteristics in areas adjacent to the Meramec River, and the initial $n$ values ranged from 0.060 to 0.100 for the flood plains.

As part of the calibration process, the initial $n$ values were varied by flow and adjusted until the differences between simulated and observed water-surface elevations at the Valley Park streamgage and at high-water marks were minimized. The final $n$ values ranged from 0.030 to 0.045 for the main channel and 0.050 to 0.130 for the flood plain areas modeled in this analysis.

\section{Hydraulic Model}

The HEC-RAS analysis for this study was done using the unsteady-state flow computation option. The unsteady flow computation (as opposed to steady-state) was selected for this hydraulic analysis to capture the flow dynamics throughout the study reach and to generate the inundation maps. Extensive analysis was completed to determine the most appropriate upstream boundary condition method. Based on model performance and differences in stage-discharge relations on the rising limb of the hydrograph compared to the falling limb (observed in field measurements and in model outputs), it was determined that the upstream boundary condition for the hydraulic model calibration would be a stage hydrograph. Stage data recorded at the Meramec River near Eureka, Mo., streamgage were used as the upstream boundary condition. Normal depths were used as the downstream boundary condition. The stage data at the Meramec River at Valley Park streamgage, about midway along the reach, were used to validate the model performance. Unsteady-state flow data consisted of flow regime, boundary conditions, and a stage hydrograph that corresponded to the flood of December 2015-January 2016. A subcritical (tranquil) flow regime was assumed for the simulations. The initial conditions for storage areas along the reach were set to closely match the water-surface elevation of the adjacent main channel cross section corresponding to the first simulated discharge.

The HEC-RAS model was calibrated to the current stage-discharge relation at the Meramec River near Eureka streamgage and to documented high-water marks surveyed by USGS personnel after the December 2015-January 2016 flood at 26 locations along the simulation reach and stage data at the Valley Park streamgage.

The model was calibrated by adjusting Manning's $n$ values and changing the ineffective flow areas, until the results of the hydraulic computations closely agreed with the observed water-surface elevations for given flows. The root mean square error computed from the differences between surveyed highwater marks in the simulation reach for the flood of December 28, 2015-January 3, 2016, and simulated peak elevations was $0.32 \mathrm{ft}$. Comparisons of hydraulic-model output and the stagedischarge rating at the Meramec River near Eureka streamgage (fig. 2) and of hydraulic-model output and high-water mark elevations (fig. 3) demonstrate that the model is capable of simulating accurate water levels for the extent of the simulation reach. 


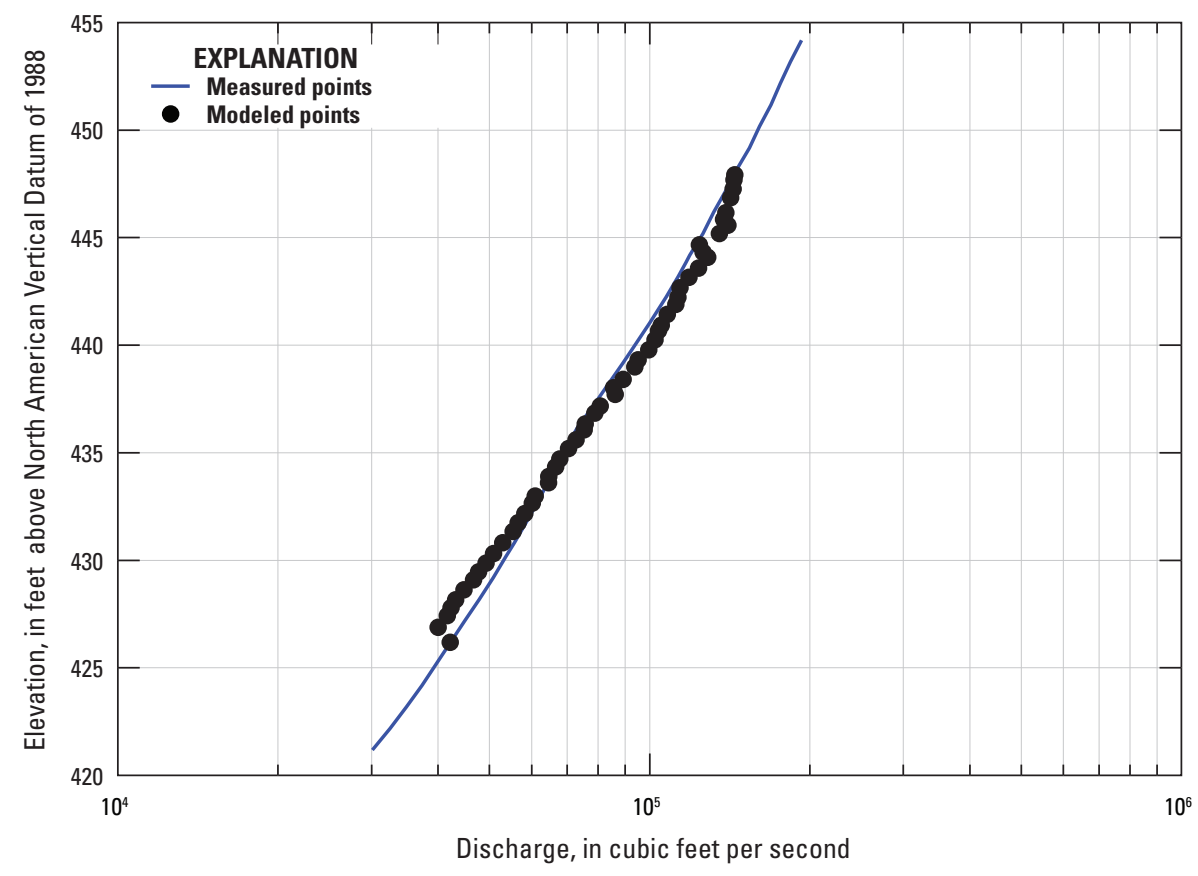

Figure 2. Comparison of hydraulic-model output and stage-discharge rating at Meramec River near Eureka, Missouri (U.S. Geological Survey station number 07019000).

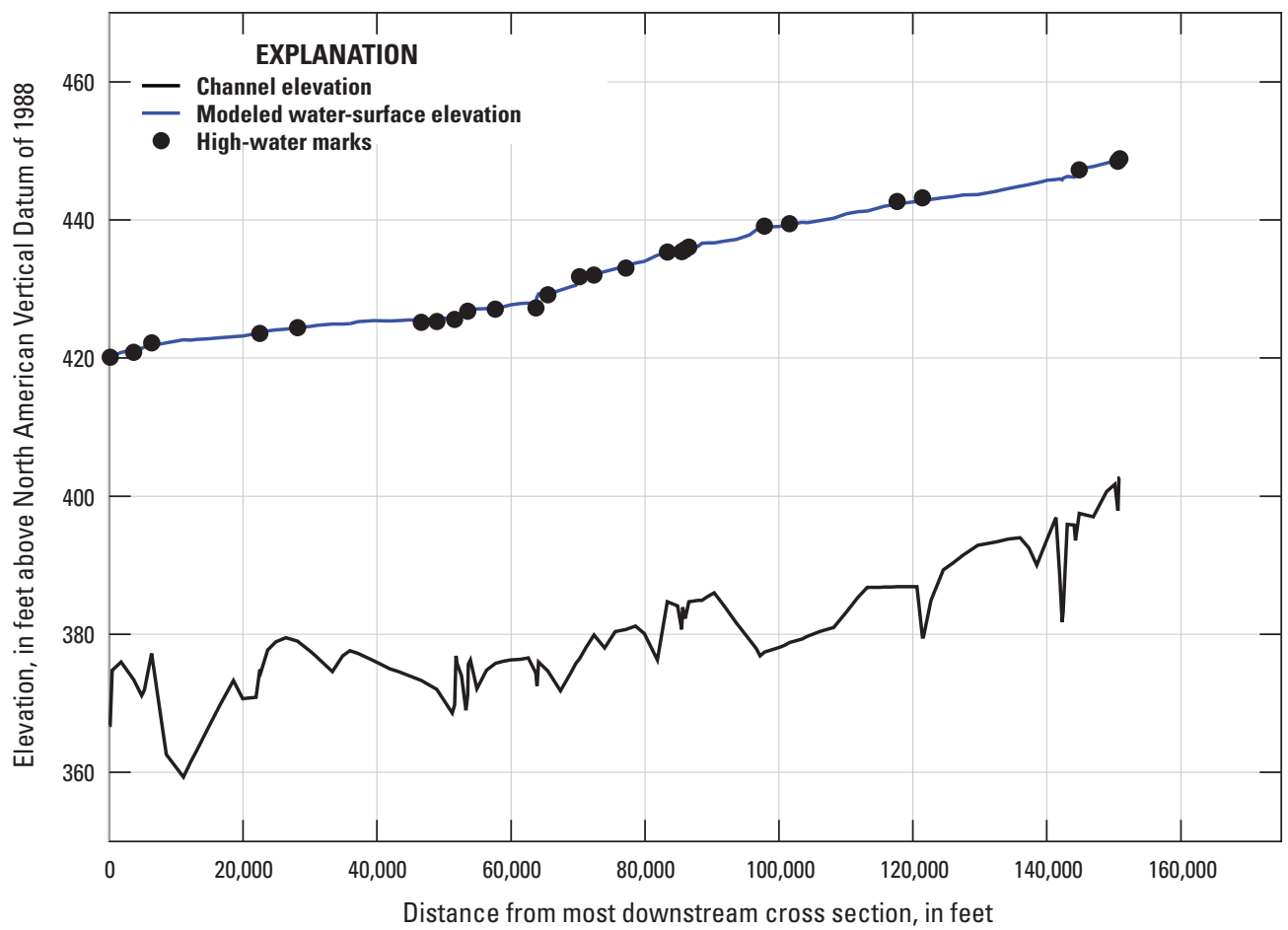

Figure 3. Comparison of hydraulic-model output and high-water mark elevations for a major flood event on December 30, 2015, Meramec River, Missouri. 


\section{Development of Water-Surface Profiles}

The calibrated hydraulic model was used to generate water-surface profiles for two sets of water surface profiles: one set associated with the Valley Park reach and streamgage 07019130, and one set associated with the Fenton reach and streamgage 07019210 . Water-surface profiles were generated for a total of 44 stages at 1 - $\mathrm{ft}$ intervals between $11 \mathrm{ft}$ and $54 \mathrm{ft}$ for streamgage 07019130 as referenced to the local streamgage datum, and these stages correspond to elevations of $402.2 \mathrm{ft}$ and $445.2 \mathrm{ft}$, NAVD 88 , respectively. A total of 30 water-surface profiles were generated for streamgage 07019210 ranging from $22 \mathrm{ft}$ to $51 \mathrm{ft}$ as referenced to the local streamgage datum, and these stages correspond to elevations of $404.8 \mathrm{ft}$ and $433.8 \mathrm{ft}$, NAVD 88 , respectively. Water surface elevations ranging from 410 to $462 \mathrm{ft}$ NAVD 88 at Meramec River near Eureka, Mo., were used as the upstream boundary condition for the HEC-RAS model. A trial and error process was used to determine the proper model inputs to simulate water-surface profiles relating to each 1-ft mapped stage at streamgages 07019130 and 07019210 to relate the boundary condition stages at the Eureka streamgage to the target stages at streamgages 07019130 and 07019210 .

\section{Development of Flood-Inundation Maps}

Flood-inundation maps were created in a GIS for the water-surface profiles by combining the profiles and DEM data. The DEM data were derived from the same lidar data described previously in the section "Topographic and Bathymetric Data" and, therefore, have an estimated vertical accuracy of $2 \mathrm{ft}$ (that is, plus or minus $1 \mathrm{ft}$ ). Estimated flood-inundation boundaries for each simulated profile were developed with HEC-GeoRAS software (Ackerman, 2009), which prepares geometric data for import into HEC-RAS and processes simulation results exported from HEC-RAS (Brunner, 2010). Shapefile polygons and depth grids of the inundated areas for each profile were modified, as required, in the ArcMap application of ArcGIS (Esri, 2017) to ensure a hydraulically reasonable transition of the flood boundaries between modeled cross sections. Although the water-surface profiles extended throughout the combined 16.7-mi reach, shapefile polygons and depths grids associated with the water surface profiles for streamgage 07019130 were clipped to the limits of the Valley Park reach. Similarly, shapefile polygons and depths grids associated with the water surface profiles for streamgage 07019210 were clipped to the limits of the Fenton reach. Any inundated areas that were detached from the main channel were examined to identify subsurface connections with the main river, such as through culverts under roadways. Where such connections existed, the mapped inundated areas were retained in their respective flood maps; otherwise, the erroneously delineated parts of the flood extent were deleted. The flood-inundation areas are overlaid on high-resolution, georeferenced, aerial photographs of the study reaches. Bridge surfaces are shown as not inundated until the lowest flood stage that either intersects the lowest structural chord of the bridge or completely inundates one or both approaches to the bridge. In these latter circumstances, the bridge surface is depicted as being inundated. Estimates of water depth can be obtained from the depth-grid data that are included with the flood maps on an interactive USGS mapping application described in the following section, "Flood-Inundation Map Delivery." The datasets (depth grids and shapefiles) used in this study are available through a data release at https:// doi.org/10.5066/F7ZG6R5R (Dietsch and Sappington, 2017). The flood map corresponding to a stage of $44 \mathrm{ft}$ for the Meramec River at Valley Park streamgage and a stage of $42 \mathrm{ft}$ for the Meramec River at Fenton streamgage are shown in figure 4.

\section{Flood-Inundation Map Delivery}

The current study documentation is available online at the U.S. Geological Survey Publications Warehouse (https://doi. org/10.3133/sir20175116). Also, a flood-inundation mapping science website (U.S. Geological Survey, 2017a) has been established to make USGS flood-inundation study information available to the public. That site links to a mapping application that presents map libraries and provides detailed information on flood extents and depths for modeled sites. The mapping application enables the production of customized flood-inundation maps from the map libraries for the Meramec River at Valley Park, Mo., and Meramec River at Fenton, Mo. A link on this website connects to the USGS National Water Information System (U.S. Geological Survey, 2017c), which presents the current stage at the cooperative USGS streamgages 07019130 and 07019210 to which the inundation maps are referenced. A second link connects to the NWS AHPS website (National Weather Service, 2017a) so the user can obtain applicable information on forecasted peak stages. The estimated floodinundation maps are displayed in sufficient detail so that preparations for flooding and decisions for emergency response can be completed efficiently. Bridge surfaces are not shadedthat is, shown as not inundated - until the lowest flood stage that either intersects the lowest structural chord of the bridge or completely inundates one or both approaches to the bridge. In these latter circumstances, the bridge surface is depicted as being shaded. A shaded building should not be interpreted to mean that the structure is completely submerged; rather, bare earth surfaces near the building are inundated. The water depth (as indicated in the mapping application by holding the cursor over an inundated area) near the building would be an estimate of the water level inside the structure, unless flood-proofing measures had been implemented.

\section{Disclaimer for Flood-Inundation Maps}

The flood-inundation maps should not be used for navigation or regulatory, permitting, or other legal purposes. The USGS provides these maps "as is" for a quick reference, emergency planning tool but assumes no legal liability or responsibility resulting from the use of this information. 
$38^{\circ} 35^{\prime}$

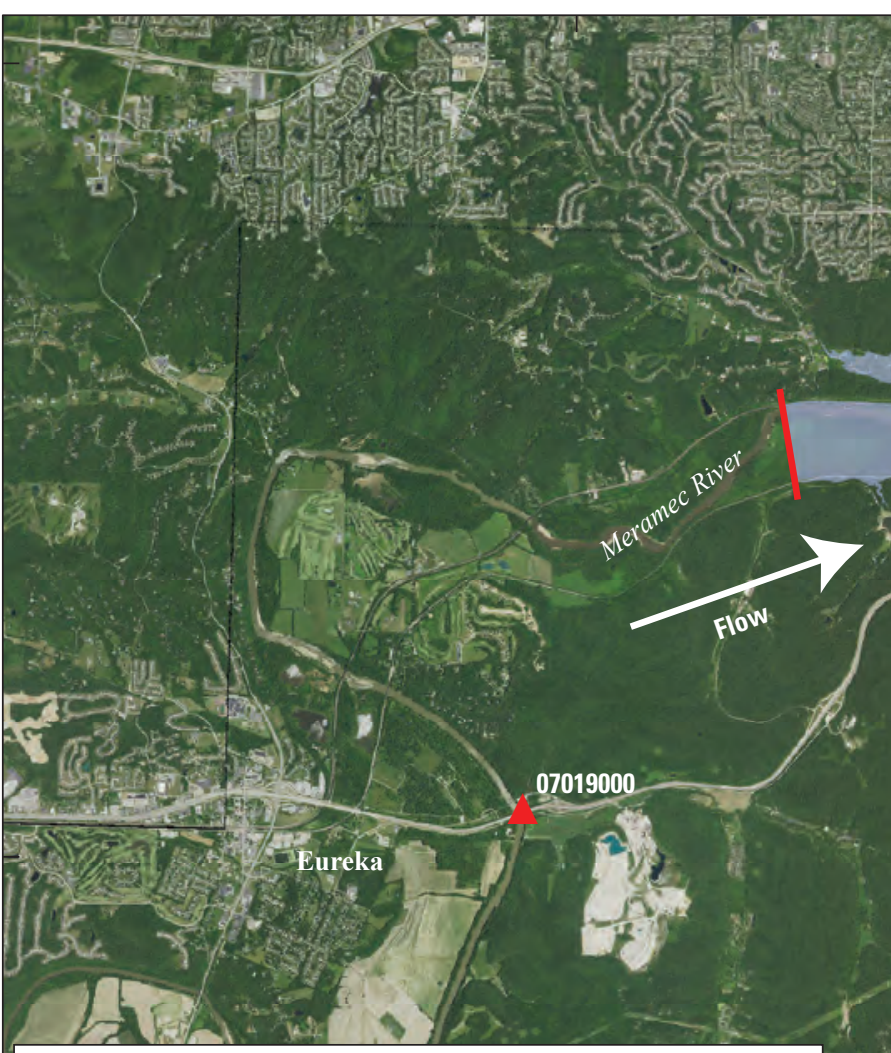

EXPLANATION

Inundated area-Stage of 44 feet at Vally Park streamgage Inundated area-Stage of 42 feet at Fenton streamgage

\section{Area of uncertainty}

Limits of study reaches

U.S. Geological Survey streamgage and number

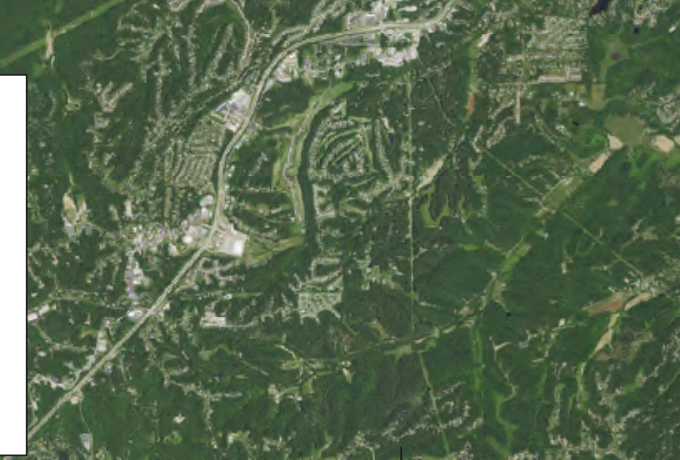

Base from U.S. Department of Agriculture National Aerial Imagery Program, 2016

Universal Transverse Mercator projection, zone 15

Horizontal coordinate information referenced to the North American Datum of 1983 (NAD 83)

Figure 4. Flood-inundation map for the Meramec River at Valley Park, Missouri, reach corresponding to a stage of 44 feet at the cooperative U.S. Geological Survey streamgage (station number 07019130) and Meramec River at Fenton, Missouri, reach corresponding to a stage of 42 feet at the U.S. Geological Survey streamgage (station number 07019210). 


\section{Uncertainties and Limitations Regarding Use of Flood-Inundation Maps}

Although the flood-inundation maps represent the boundaries of inundated areas with a distinct line, some uncertainty is associated with these maps. The flood boundaries shown were estimated based on water stages and discharges at selected USGS streamgages. Water-surface elevations along the stream reaches were estimated by unsteady-state hydraulic modeling, assuming unobstructed flow, and using discharges and hydrologic conditions anticipated at the USGS streamgage(s). The hydraulic model reflects the land-cover characteristics and any bridge, dam, levee, or other hydraulic structures existing as of December 2015. Unique meteorological factors (timing and distribution of precipitation) may cause actual discharges along the modeled reach to differ from those assumed during a flood, which may lead to deviations in the water-surface elevations and inundation boundaries shown. Additional areas may be flooded because of unanticipated conditions such as changes in the streambed elevation or roughness, backwater into major tributaries along a main stem river, or backwater from localized debris or ice jams. The accuracy of the floodwater extent portrayed on these maps will vary with the accuracy of the DEM used to simulate the land surface.

If this series of flood-inundation maps will be used in conjunction with NWS river forecasts, the user should be aware of additional uncertainties that may be inherent or factored into the NWS forecast procedures. The NWS uses forecast models to estimate the quantity and timing of water flowing through selected stream reaches in the United States. These forecast models (1) estimate the amount of runoff generated by precipitation and snowmelt, (2) simulate the movement of floodwater as it proceeds downstream, and (3) predict the flow and stage (and water-surface elevation) for the stream at a given location (AHPS forecast point) throughout the forecast period (every 6 hours and 3 to 5 days out in many locations). For more information on AHPS forecasts, please see http://water.weather.gov/ ahps/pcpn_and_river_forecasting.pdf.

Another source of uncertainty relevant to the study reach is the Valley Park levee system, which, if breached, can produce variable flood extents and water depths on the landward side of the levee. Additional uncertainties and limitations pertinent to this study may be described elsewhere in this report.

\section{Summary}

A series of digital flood-inundation maps were developed in cooperation with the U.S. Army Corps of Engineers, St. Louis Metropolitan Sewer District, Missouri Department of Transportation, Missouri American Water, and Federal Emergency Management Agency Region 7 and referenced to the Meramec River at Valley Park, Missouri, and the Meramec River at Fenton, Mo., streamgages. The maps cover a 16.7mile (mi) long reach extending from upstream from Valley Park, Mo., to a location downstream from Fenton, Mo. The reach at Meramec River at Valley Park, Mo., is $9.1 \mathrm{mi}$, and the reach near Meramec River at Fenton, Mo., is $7.6 \mathrm{mi}$. The maps were developed using the U.S. Army Corps of Engineers Hydrologic Engineering Centers River Analysis System (HEC-RAS) program to compute water-surface profiles and to delineate estimated flood-inundation areas and depths of flooding for selected stream stages. The HEC-RAS hydraulic model was calibrated to a stage-discharge rating at the Meramec River near Eureka streamgage and to high-water marks from the December 2015-January 2016 flood. The model was used to compute water-surface profiles for 1-foot stage intervals referenced to the local streamgage datum at the Meramec River at Valley Park and the Meramec River at Fenton streamgages. The simulated stages of each set of profiles ranged from the National Weather Service action stage (about bankfull flow) to the stage corresponding to the estimated 0.2-percent annual exceedance probability (500year recurrence interval) flood at the Meramec River near Eureka streamgage. The simulated water-surface profiles were then combined with a geographic information system digital elevation model derived from light detection and ranging data to delineate estimated flood-inundation areas as shapefile polygons and depth grids for each profile. These flood-inundation polygons were overlaid on high-resolution, georeferenced aerial photographs of the study reaches. The flood maps are available through a mapping application that can be accessed on the U.S. Geological Survey (USGS) Flood Inundation Mapping Science website (https://water.usgs.gov/ osw/flood_inundation).

The interactive maps on this mapping application can give users a general indication of depth of water at any point by clicking within the shaded areas using the mouse cursor. These maps, in conjunction with the real-time stage data from the cooperative USGS streamgages, Meramec River at Valley Park (USGS station number 07019130) and Meramec River at Fenton (USGS station number 07019210), and forecasted flood stage data from the National Weather Service Advanced Hydrologic Prediction Service, will help to guide the general public in taking individual safety precautions and will provide emergency management personnel with a tool to efficiently manage emergency flood operations and postflood recovery efforts.

\section{References Cited}

Ackerman, C.T., 2009, HEC-GeoRAS, GIS tools for support of HEC-RAS using ArcGIS, user's manual, version 4.2: U.S. Army Corps of Engineers, Hydrologic Engineering Center [variously paged]. 
Barnes, H.H., Jr., 1967, Roughness characteristics of natural channels: U.S. Geological Survey Water-Supply Paper 1849,213 p. [Also available at https://pubs.usgs.gov/wsp/ wsp_1849/pdf/wsp_1849.pdf.]

Brunner, G.W., 2010, HEC-RAS River Analysis System, hydraulic reference manual, version 4.1: U.S. Army Corps of Engineers, Hydrologic Engineering Center [variously paged].

Brunner, G.W., 2016, HEC-RAS River Analysis System, hydraulic reference manual, version 5.0: U.S. Army Corps of Engineers, Hydrologic Engineering Center [variously paged].

Coon, W.F., 1998, Estimation of roughness coefficients for natural stream channels with vegetated banks: U.S. Geological Survey Water-Supply Paper 2441, 133 p. [Also available at https://pubs.usgs.gov/wsp/2441/report.pdf.]

Dewberry, 2012, National Enhanced Elevation Assessment: Fairfax, Va., Dewberry, 84 p., accessed April 5, 2017, at http://www.dewberry.com/docs/default-source/documents/ neea_final-report_revised-3-29-12.pdf?sfvrsn $=0$.

Dietsch, B.J., and Sappington, J.N., 2017, Flood-inundation maps for the Meramec River at Valley Park and at Fenton, Missouri, 2017: U.S. Geological Survey data release, https://doi.org/10.5066/F7ZG6R5R.

Esri, 2017, ArcGIS: Esri, accessed February 6, 2017, at http:// www.esri.com/software/arcgis/.

Federal Emergency Management Agency, 2015, Flood insurance study, St. Louis County, Missouri, and incorporated areas: Washington D.C., Federal Emergency Management Agency, 202 p.

Holmes, R.R., Jr., Koenig, T.A., Rydlund, P.H., and Heimann, D.C., 2016, Examination of flood characteristics at selected streamgages in the Meramec River Basin, Eastern Missouri, December 2015-January 2016: U.S. Geological Survey Open-File Report 2016-1140, 7 p., accessed March 28, 2017, at https://doi.org/10.3133/ofr20161140.

King, H.W., and Brater, E.F., 1963, Handbook of hydraulics (5th ed.): New York, McGraw Hill Book Company, 1373 p.

Missouri Department of Natural Resources, 2015, The state of our Missouri waters, Meramec River watershed: Missouri Department of Natural Resources web page, accessed April 6, 2017, at https://dnr.mo.gov/env/docs/2015MeramecWater shedSummary.pdf.

National Weather Service, 2017a, Advanced Hydrologic Prediction Service: National Weather Service web page, accessed March 28, 2017, at http://water.weather.gov/ahps/ forecasts.php.
National Weather Service, 2017b, National Weather Service glossary: National Weather Service web page, accessed February 6, 2017, at http://w1.weather.gov/glossary/index. php? word=action+stage.

National Weather Service, 2017c, National Weather Service glossary: National Weather Service web page, accessed February 6, 2017, at http://w1.weather.gov/glossary/index. php? word=Flood + Categories.

Omernik, J.M., 1987, Ecoregions of the conterminous United States: Annals of the Association of American Geographers, v. 77 , no. 1 , p. 118-125, scale 1:7,500,000.

Surdex Corporation, 2012a, Missouri Counties lidar project-April 20, 2012: Lidar Acquisition and Processing Report, accessed March 9, 2017, at ftp://lidar.wustl.edu/ StLouis2012/Project\%20Data/Reports/LiDAR\%20Acquistition-Processing\%20Summary\%20St\%20Louis.pdf.

Surdex Corporation, 2012b, Missouri Counties lidar project-May 1, 2012: Lidar Accuracy Report, accessed March 9, 2017, at ftp://lidar.wustl.edu/StLouis2012/Project\%20Data/Reports/ LiDAR\%20Accuracy\%20Report\%20St\%20Louis.pdf.

U.S. Army Corps of Engineers, 2017, National Levee Database: U.S. Army Corps of Engineers web page, accessed March 9, 2017, at http://nld.usace.army.mil/egis/ $\mathrm{f} ? \mathrm{p}=471: 1: 0:: \mathrm{NO}$.

U.S. Census Bureau, 2010, 2010 census interactive population search-Missouri: U.S. Census Bureau web page, accessed March 2017 at http://www.census.gov/2010census/popmap/ ipmtext.php?fl=29.

U.S. Geological Survey, 2017a, USGS Flood Inundation Mapping Program: U.S. Geological Survey web page, accessed February 6, 2017, at http://water.usgs.gov/osw/flood_inundation.

U.S. Geological Survey, 2017b, USGS surface-water data for the Nation: U.S. Geological Survey National Water Information System-Web interface, accessed February 6, 2017, at https://doi.org/10.5066/F7P55KJN.

U.S. Geological Survey, 2017c, USGS 07019000 Meramec River near Eureka, MO: U.S. Geological Survey, accessed February 6, 2017, at http://waterdata.usgs.gov/mo/nwis/ uv?site_no $=07019000$. 
Publishing support provided by: Rolla Publishing Service Center

For additional information concerning this publication, contact: Director, USGS Missouri Water Science Center 1400 Independence Road Rolla, M0 65401

(573) 308-3667

Or visit the Missouri Water Science Center Web site at: https://mo.water.usgs.gov 


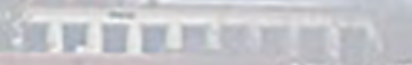

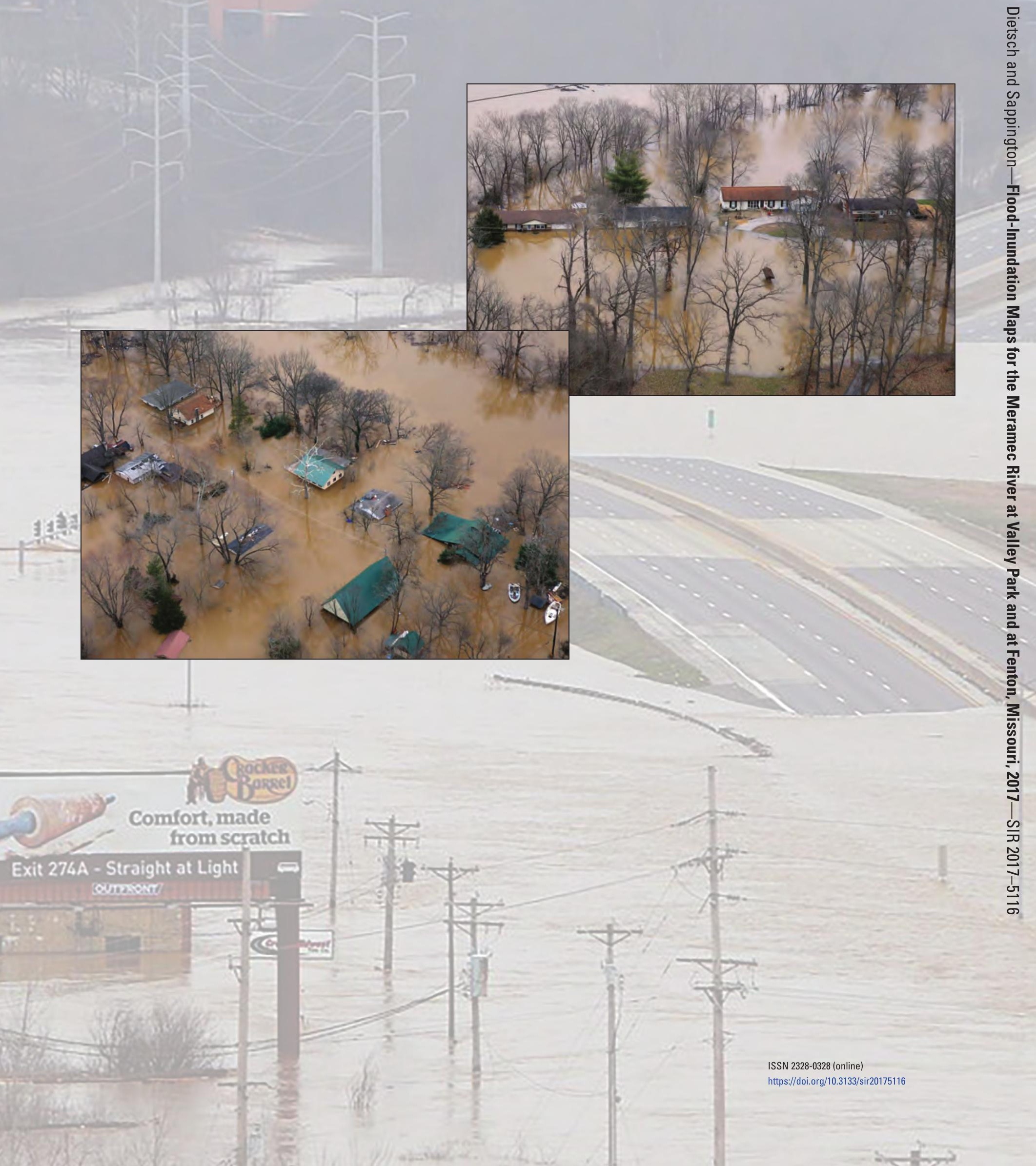

